\author{
Raminta Stankuté-Søsted ${ }^{*}$ \\ Institute of International Relations and Political Science, Vilnius University
}

\title{
The Susceptibility of Lithuanian Youth to Information Attacks: the Elaboration Likelihood Model and Presumable Attack Topics
}

\begin{abstract}
This article examines the susceptibility of Lithuanian youth to information attacks aimed at psychologically influencing them, i.e., changing or shaping their attitudes. It raises the question whether the bias of Lithuanian youth towards news sources and their passivity regarding political news can make them vulnerable to attacks. To answer the question, insights from propaganda and persuasion studies were applied to design a quasi-experimental study. The overall evaluation showed that the attitude of all the participants in the study significantly worsened after receiving propaganda information about the EU situation, their country's political institutions, and the Polish minority. The study did not find sufficient evidence that Lithuanian youth participating in the study were more susceptible to propaganda products when they were not motivated to elaborate the information provided to them even though it came from a potentially credible source.
\end{abstract}

\section{Introduction}

Today information attacks seem to be shaking the very foundations of democracy and because of their main target, i.e., the society; these attacks becoming a major security challenge. As technology advances the 'fog' descends upon the truth not only during the war, but also in the time of peace. Consequently, it makes it increasingly difficult to distinguish reality from a false construct, ${ }^{1}$ and today even the world's most powerful nation, the United States, is still struggling to comprehend the fact that a hostile state had an impact

\footnotetext{
${ }^{*}$ Raminta Stankuté-Søsted is an Alumnus of the Institute of International Relations and Political Science, Vilnius University. Address for correspondence: Vokiečių str. 10, LT-01130 Vilnius; Lithuania, tel. +370-5-2514130, e-mail: stankute.raminta@gmail.com ${ }^{1}$ Warzel C. (2018), "He Predicted the 2016 Fake News Crisis. Now He's Worried About An Information Apocalypse”. Available at: https://www.buzzfeed.com/charliewarzel/the-terrifying-future-of-fakenews?utm_term=.lrxY4BZOp\#.csOpdWko4, (Accessed: 25 November 2018).
}

DOI: 10.2478/lasr-2019-0014

(C) Raminta Stankutè-Søsted, 2019

(C) Military Academy of Lithuania, 2019 
on the country's presidential election through information attacks. ${ }^{2}$ Obviously, aspirations to reach audiences are becoming more ambitious and précis and like never before in history they are enabled by a low-effort requiring distribution platform - social media.

The on-going information battles do not pass by Lithuania. The country shares a border with Russia, one of the most active participants in information battles. Researchers and experts say that nostalgia for the Soviet era and the susceptibility of minorities help Russian narratives to take root in Lithuania. As the country seeks to strengthen its resistance to propaganda, the hope rests with the succeeding generation. It is hoped that a generation that was not 'corrupted' by the Soviet-era will help stabilize the country's information field. ${ }^{3}$ However, given the global trends, it is naive to expect this. Keir Giles, a security expert interested in Russian security, notes though Russia inherited the tools used in the Soviet times, the approach has changed. The main difference is the disappearance of a single ideology, so today's narratives are inconsistent and even conflicting compared to the Soviet era. Russia no longer follows a single course, now it can support any form of protest in the country - the radical right, the radical left or anything in-between. It seeks to constantly transform reality and create multiple realities, and the only unifying characteristic is the promotion of distrust and hostility towards the political system of the targeted country. Notable examples include German leftists receiving pacifist memes which reinforce the notion that US militarism poses a challenge to the peace, French radical rightists receiving messages that encourage saving the Christianity, and Slovaks receiving messages about German dominance in the EU. ${ }^{4}$ So, while Lithuania is hoping for the generation of independence to be less susceptible to propaganda, it is worth examining it closer, especially given the great neighbor's ingenuity in the information warfare.

After the events in the Crimea, that demonstrated the effectiveness of hybrid warfare, Lithuania intensified its search for a suitable model which could help to analyze propaganda and to assess the resistance to information attacks of the society. Today, one can access the latest studies that provide a comprehensive overview of the field of information battles in Lithuania. It is

\footnotetext{
${ }^{2}$ Alvarez P. and Hosking T. (2018), “The Full Text of Mueller's Indictment of 13 Russians”. Available at: https://www.theatlantic.com/politics/archive/2018/02/rosenstein-mueller-indictment-russia/553601/?utm_ source=newsletter\&utm_medium=email\&utm_campaign=atlantic-daily-newsletter\&utm_content=2018021 6\&silverid=MzEwMTkwMTMxMTc3S0, (Accessed: 25 November 2018).

${ }^{3}$ Rytų Europos studijų centras (2017), Rusijos propaganda: analizė, įvertinimas, rekomendacijos, Vilnius: RESC, p. 135.

${ }^{4}$ Center for European Policy Analysis (2016), Winning the Information War: Techniques and CounterStrategies in Russian Propaganda. Washington, DC: The Legatum Institute, p. 6-7.
} 
worth to mention the dissertation (2008) by Nerijus Maliukevičius The Potential of Russia's Geopolitics of Information; the article "Propaganda Research Model for the Analysis of Russian Propaganda in Lithuania" by Darius Buinauskas et al.published in 2016; a monograph Russian Propaganda: Analysis, Evaluation, Recommendations published by RESC in 2017; and, finally, study by Aine Ramonaite et al. Who Would Defend Lithuania? published in 2018. These works analyze the susceptibility of Lithuanian society to propaganda and apply models that allow us to look deeper into this phenomenon. They present a deep understanding of the susceptibility of the Soviet generation and ethnic minorities, but do not take into account the distinctive features of the independence generation e.g. different historical experiences, low knowledge in the Russian language, different media habits, etc.

In 2016 was published a noteworthy study Media consumption habits of Lithuanian and non-Lithuanian youth, which observes certain characteristics of Lithuanian youth. Young people tend to gain knowledge from Facebook and regular updates from the most popular portals (Delfi, $15 \mathrm{~min}$, etc.). ${ }^{5}$ Members of national minorities and native Lithuanians both tend to show little interest in the events of Lithuania or the world and they also tend to display a lack of critical thinking over the information they receive. Though comparing to minorities' youth it was noticed that especially native Lithuanian youth exhibit a lower level of critical evaluation over the incoming information. Native Lithuanian youth tend to believe what they read. Finally, young people themselves reported that they have noticed that their close relatives, i.e., older generation, are much more interested in political news than they are. ${ }^{6}$ All of this portrays an image of young people who are passive and have a strong trust (if not biased) in media sources and channels. Therefore, given that one of the main tasks of information attacks, for them to be successful, is to understand their audience's peculiarities and characteristics; the above-stated situation of youth signals that in the currently existing research into susceptibility of Lithuanian society to propaganda does not see the full picture of the vulnerability of Lithuanian society. Thus, it can be argued that the country lacks analysis that directly investigates the importance of the independence generation characteristics in the field of information warfare.

Therefore the main question raised in this article is: can native Lithuanian youth be susceptible to information attacks ${ }^{7}$ if their identified vulnerabi-

\footnotetext{
${ }^{5}$ TNS LT (2016), Lietuviu ir nelietuviu jaunimo medijų vartojimo įpročiai, Vilnius, p. 7-8.

${ }^{6}$ Ibidem, p. 9-10.

${ }^{7}$ This study is limited to information attacks aimed at psychologically affecting individuals or a group of individuals.
} 
lities are exploited? Sensitivity or vulnerability is understood to be a property that can be used to cause harm or injury, ${ }^{8}$ but those are not necessarily being exploited at the moment. In summary, the following vulnerabilities can be distinguished: passivity towards political news, lack of critical assessment of the information received and bias towards the source. It should be noted that this study focuses only on the native Lithuanian youth since the ethnic minorities are analyzed in detail in the currently existing studies (e.g. the RESC monograph).

\section{The Relationship between Persuasive Communication and Propaganda: Research Opportunities}

Almost everything related to shaping and changing attitudes has an element of persuasion; therefore the persuasion studies seek an in-depth understanding of attitudes and comprehension of the means that assist in changing them. ${ }^{9}$ The persuasion is defined as a communicative process in which the communicator seeks to elicit the desired response from the recipient. ${ }^{10}$ It is not analogous to telling the truth: the main purpose of persuasion is to gain influence, not to spread the truth, thus, persuaders can hide the truth or even mislead the recipient as long as it serves their purpose, therefore techniques applied by the persuader remains a matter of ethics. ${ }^{11}$ Persuasion contains two important elements: the persuader is conscious of the fact that he is trying to influence others, ${ }^{12}$ and the persons who are being influenced have the freedom of choice, ${ }^{13}$ i.e., they may opt for a different behavior from the one that is offered to them. ${ }^{14}$

Garth S. Jowett and Victoria O'Donnell in the book Propaganda and Persuasion refers to an intertwined history of propaganda and persuasion, one of the notable examples being Harold D. Laswell's model which set the foun-

\footnotetext{
${ }^{8}$ Brauch H. G. (2011), “Concepts of Security Threats, Challenges, Vulnerabilities, and Risks”, Brauch H. G. et al., Coping with Global Environmental Change, Disasters and Security. Berlin: Springer, p. 73.

${ }^{9}$ Perloff M. R. (2010), The Dynamics of Persuasion: Communication and Attitudes in the 21st Century, London: Routledge, p. 3.

${ }^{10}$ Ibidem, p. 11.

${ }^{11}$ Ibidem, p. 33.

${ }^{12}$ Ibidem, p. 11.

${ }^{13}$ Coercion can also change attitudes and behaviors, but that has nothing to do with persuasion (Perloff, 2010, p. 19).

${ }^{14}$ Ibidem, p. 33.
} 
dation of today's propaganda studies. The mentioned model was built based on stimulus-response model ${ }^{15}$ specific to the field of persuasive communication. Therefore, one can assume that understanding how attitudes are formed and shaped helped to understand that the effect of propaganda and persuasion is dependent on the context (e.g. historical memory), individual differences and various intervening variables. ${ }^{16}$

Although there is no clear consensus on the term 'propaganda, ${ }^{17}$ there is a common perception that it involves purposefully generated information used for targeting audiences to influence their attitudes and actions. In other words, it is an intentional and systematic attempt to shape perception, manipulate knowledge or modify behavior so that the elicited response would contribute to the desired goals of the propagandist. ${ }^{18}$ Laswell viewed propaganda from a scientific point of view and proved that communication is a science, and propaganda is the object of that science. Hence there is an obvious connection between propaganda and persuasive communication, one of them being that in both cases the communicator consciously seeks a change in attitude or behavior. Although Anthony R. Pratkani and Elliot Aronson argue that persuasion cannot always be identified as propaganda, because from a traditional standpoint propaganda is based on the manipulation of symbols and personal psychology, ${ }^{19}$ which is less commonly seen as part of persuasion, since persuasion has a more positive connotation. ${ }^{20}$ Still, manipulation is also attributed to persuasive communication as it is one of the techniques which are used now and then, though it is not a dominant one. ${ }^{21}$ Thus, persuasive communication is commonly seen in a positive light, while propaganda is seen in a negative one, and yet manipulation is a characteristic of them both. Also, according to Richard M. Perloff, propaganda stands out due to its massive scale, as it is usually aimed at persuading through mass media, while persuasive communication works on a smaller scale. However, Jowett and O'Donnell note that while traditionally propagandists choose a mass audience, an aim to affect smaller groups or an aim to effect individuals is also plausible as long as it serves for the goals of the propagandist. ${ }^{22}$ Perloff also argues that persuasive communication is usually not as disguised as propaganda and allows information

\footnotetext{
${ }^{15}$ Jowett G. S. and O’Donnell V. (2012), Propaganda and Persuasion. USA: SAGE, p. 168.

${ }^{16}$ Ibidem, p. 165.

${ }^{17}$ Rytų Europos studijų centras (footnote 3), p. 19.

${ }^{18}$ Ibidem, p. 21.

${ }^{19}$ Ibidem, p. 24.

${ }^{20}$ Perloff (footnote 9), p. 24.

${ }^{21}$ Ibidem, p. 24.

${ }^{22}$ Jowett, O’Donnell (footnote 15), p. 296.
} 
flow in the information field. While in the case of propaganda, there is usually a total control over the transmission of information. ${ }^{23}$ However, total control is more typical of world war periods and the Cold War. Nowadays, especially in democratic countries, the flow of information is diverse and poorly limited, which does not hinder propaganda, but helps to disseminate it and due the speed in which information online is spread the propaganda today has a potency to gain an incredible scale and capacity.

To summarize, the persuasion studies help us to understand the effect of persuasion on attitudes and behaviors, i.e., how and why attitudes and behaviors can be altered ${ }^{24}$ through communication. However, this knowledge does not help us to comprehend the full picture of the information battlefield when countries are fighting each other. When it comes to psychologically influencing the population of another country, it is important to comprehend not just mechanisms behind the attitude change, but also the unique ways one can do that, i.e., it is crucial to understand the social, cultural and economic context of the country, group, etc. It is precisely the propaganda studies that help us to understand how the context is analyzed when the aim is to psychologically influence a population of a country or its specific groups. Thus, it can be argued that the realization of the close relationship between persuasive communication and propaganda can enrich the quest for a better model to analyze information attacks that seek to effect psychologically.

\subsection{Jowett and O'Donnell's Model of Propaganda Analysis: Contextual Analysis}

In the case of information attacks, the grasp of the unique characteristics of the target and its environment is a significant aspect of the effectiveness of the attacks. Propaganda as a process is socially determined, therefore to understand how it functions in society, we have to understand how the existing socio-cultural context allows/helps it to perform. Jowett and O'Donnell underline such sociocultural elements as ideology, social myths, the government, the economy, social practices, and specific events, basically everything that can influence propaganda. That is why it manifests itself differently in different societies..$^{25}$

\footnotetext{
${ }^{23}$ Perloff (footnote 9), p. 20.

${ }^{24}$ It should be noted that this analysis focuses only on the element of attitude since the element of change in behavior requires an additional study.

${ }^{25}$ Jowett, O’Donnell (footnote 15), p. 360-361.
} 
Jowett and O'Donnell's propaganda analysis model consists of ten steps ${ }^{26}$ but only the context step in which propaganda occurs is used in this analysis. The whole model cannot be applied for this susceptibility analysis because currently there is no evidence that native Lithuanian youth is explicitly under attack. On the contrary, as mentioned in introduction the minorities (which uses Russian language or media on everyday basis) or people who are nostalgic about Soviet-era are the main targets and because propaganda analysis in this model is carried out top-down, i.e., one starts with the bigger picture (understanding of propagandist ideas, goals and ideologies) and moves on to the targeted group, therefore the challenge to be able to analyze the vulnerability of a particular group of society starting not with propagandist arise. This analysis had to be carried out bottom-up, i.e., starting with the group and only briefly getting to know the propagandist who is constantly interested in Lithuania as it is an unchangeable part of the country. In order to meet the challenge, a persuasive communication model was used to look at society's vulnerability bottom-up, i.e., begin with the group. However, contextual analysis remains an important component of the study which plays a part in understanding the fertile ground for propaganda and helps to formulate hypotheses.

The literature referred to in the introduction identifies the frame for analyzing directions Russian of attacks on the Lithuanian society in information battles (see Table 1). Thus, keeping in mind that the country is a neighbor with aggressor, i.e., Russia, who is interested in destabilizing the society, the youth was viewed in this analysis through the lens of these topics in the frame. Following the questions proposed by Jowett and O'Donnell as guidelines (see Table 1), each division was considered from the perspective of the youth group in order to identify possible topics through which youth could be influenced by propaganda or similar (see Table 2 ). The hypotheses and stimuli were formatted according to evaluations made during this context part.

\footnotetext{
${ }^{26}$ Ibidem, p. 290.
} 


\section{Table 1. Directions of Information Attacks in Lithuania and Possible Analysis Questions}

\begin{tabular}{|c|c|}
\hline Frame topics & Possible questions. Jowett and O'Donnell's model \\
\hline $\begin{array}{l}\text { 1. Increasing distrust in the country's } \\
\text { political institutions. } \\
\text { 2. Image of Lithuania as a failed state. } \\
\text { 3. Increasing mistrust in the country's allies - } \\
\text { NATO and the EU. } \\
\text { 4. The West-East divide: promoting conservative } \\
\text { values as opposed to the Western ones. } \\
\text { 5. Increasing the divide and strife between } \\
\text { national minorities and Lithuanians. } .^{* *}\end{array}$ & $\begin{array}{l}\text { a) What is expected of the system? } \\
\text { b) What are the prevailing moods? } \\
\text { c) What problems can be identified? } \\
\text { How widely are they understood? } \\
\text { What prevents them from being } \\
\text { resolved? } \\
\text { d) What historic events could have } \\
\text { determined this situation? } \\
\text { e) What values could be important in this } \\
\text { situation? } \\
\text { What myths could be related to this }\end{array}$ \\
\hline
\end{tabular}

\section{Table 2. Analysis of the Context of Lithuanian Youth}

\begin{tabular}{|c|c|}
\hline Topic & Main statements and arguments in the analysis of the context of Lithuanian youth \\
\hline 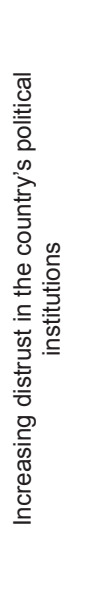 & $\begin{array}{l}\text { 1. Compared to the rest of the society the youth has more public spirit, }{ }^{3^{*}} \text { but there remains a } \\
\text { problem of their low and passive engagement or interest in politics } .^{*}{ }^{*} \text { However, the poor youth } \\
\text { engagement in politics is observed worldwide and it is argued that it stems from their inability } \\
\text { to cover the entire spectrum of political issues and as it happens they tend to focus on one } \\
\text { issue and create its escalation in social media. Therefore, it is claimed that not voting can } \\
\text { express skepticism, but not apathy } 5^{5^{*}} \text { as youth tend to find other ways to show their political } \\
\text { interest (e.g. protests, social media campaigns, etc.). In } 2018 \text { we can observe some of such } \\
\text { incidents in Lithuanian too, e.g. \#MeToo or the protest Mes kaltinam! (We accuse!). } \\
\text { 2. The opting-out to vote in elections and having the representatives elected by the older gen- } \\
\text { eration creates a vacuum between the younger generation and those elected to govern. It } \\
\text { can be argued that this vacuum can get filled by radical or populist movements as there } \\
\text { are such occurrences already spreading in Europe. }{ }^{6^{*}} \text { Nevertheless, yet no signs have been } \\
\text { noticed of youth radicalization in Lithuania because the traditional parties are the ones youth } \\
\text { chooses to vote for. }{ }^{7^{*}} \\
\text { However, as long as there is a vacuum there is a possibility to expand it and, as } 2018 \text { has } \\
\text { demonstrated, there is a possibility to mobilize the younger generation in order to achieve } \\
\text { an 'explosive' dissatisfaction effect. This could be used by an attacker, i.e., propagandist,, } \\
\text { to disbalance the government that is not favored by him (e.g. by spreading suspicion about } \\
\text { harassment, ties with Russia, etc.) or even increase the support for favorable elite represen- } \\
\text { tatives, as such disbalance-support tactic was demonstrated in } 2016 \text { USA election. } .^{8^{*}}\end{array}$ \\
\hline
\end{tabular}

${ }^{1^{*}}$ Ramonaite A. (2018), “(Ne)atsparumas Rusijos propagandai: priežastys ir padariniai”, Ramonaitė A. et al., Kas eitų ginti Lietuvos? Pilietinio pasipriešinimo prielaidos ir galimybès, Vilnius: Aukso žuvys, p. 142.

$2^{2^{*}}$ Jowett, O’Donnell (footnote 15), p. 292.

${ }^{3 *}$ Ramonaitè A. (2018), "İvadas”, Ramonaitè, A. et al., Kas eitu ginti Lietuvos? Pilietinio pasipriešinimo prielaidos ir galimybès, Vilnius: Aukso žuvys, p. 15.

${ }^{4}$ Baltrukevičius M. (2017), "Balsuosiu kai pasensiu, arba apie jaunimo (ne)dalyvavimą Lietuvoje”. Available at: http://www.bernardinai.lt/straipsnis/2017-06-16-balsuosiu-kai-pasensiu-arba-apie-jaunimo-politini-ne-dalyvavima-lietuvoje/160647, (Accessed: 27 October 2018).

$5^{*}$ Šuminas A. and Mierzecka A. (2014), "Political information sources for young citizens: a case study of Lithuanian youth information behavior", Informacijos mokslai (No. 70), p. 26-27.

$6^{*}$ TV3 (2012), “Radikalus jaunimas Lietuvoje: saviraiškos laisvė ar anarchijos užuomazgos? (I)”. Available at: https://www.tv3.lt/naujiena/jaunimas/588016/radikalus-jaunimas-lietuvoje-saviraiskos-laisve-aranarchijos-uzuomazgos-i, (Accessed: 27 November 2018).

$7^{7 *}$ ELTA (2016), “Apie penktadali balsų rinkimuose nulemė jauni žmonės”. Available at: https://www.delfi. lt/news/daily/lithuania/apie-penktadali-balsu-rinkimuose-nuleme-jauni-zmones.d?id=72526576, (Accessed: 27 October 2018).

$8^{*}$ Swaine J. (2018), "Russian propagandists targeted African Americans to influence 2016 US election," The Guardian. Available at: https://www.theguardian.com/us-news/2018/dec/17/russian-propagandiststargeted-african-americans-2016-election, (Accessed: 30 September 2019). 


\begin{tabular}{|c|c|c|}
\hline 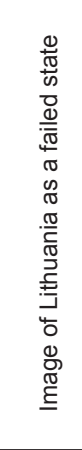 & 2. & $\begin{array}{l}\text { Lithuanian press portrays a typical picture of emigrant as } 29 \text { years old or younger person } \\
\text { who is unmarried, with secondary or vocational education. }{ }^{* *} \text { Also, in the country press, there } \\
\text { is a highlight on a survey of young people between } 15 \text { and } 19 \text { years old, in which it is discov- } \\
\text { ered that as many as } 90 \% \text { of respondents claim that they would leave their homeland if they } \\
\text { would find a decent job abroad. } .^{10^{*}} \text { It is also claimed that every third of young people would } \\
\text { leave the country permanently. } 1^{11^{*}} \\
2016 \text { saw the fourth wave of country's emigration and this wave is exceptional in a manner } \\
\text { that even as many as } 46 \% \text { of interviewed emigrants see Lithuania as their true home. } .^{12^{*}} \text { It } \\
\text { is worth considering the possibility that the people who hold their homeland their true home } \\
\text { might just be pushed out from it and what we see are signals of a strong disappointment with } \\
\text { the current situation in the country (e.g. unemployment, low wages, etc.). Thus, the image of } \\
\text { a 'failing' country from which every third young person wants to flee, automatically emerges } \\
\text { in front of the readers' eyes. This is a beneficial situation in the information war because all } \\
\text { the attacker has to do now is to strengthen the disappointment moods and help to deepen } \\
\text { the problem. }\end{array}$ \\
\hline 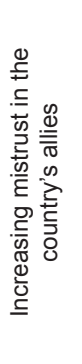 & 2. & $\begin{array}{l}\text { Lithuanian society has a high trust in the NATO }{ }^{13^{*}} \text { and one of the preconditions for this trust } \\
\text { is the war memory, i.e., it is believed that the countries that were the most affected by WWII, } \\
\text { the Cold War and relations with Russia tend to trust the NATO and even their own national } \\
\text { forces more. }{ }^{14^{*}} \text { It could be argued that the independence generation is the generation whose } \\
\text { historical memory is dominated by the discourse of victimization which happened during all } \\
\text { the events mentioned earlier, e.g. occupation by Russia, guerrilla resistance, citizens' depor- } \\
\text { tations to Siberia, and events of January } 13 \text { and so on. Therefore, in the context of informa- } \\
\text { tion warfare, young people's confidence in NATO can hardly be shaken. } \\
\text { Although Lithuania is characterized by exceptionally high levels of trust in the EU, it is hy- } \\
\text { pothesized that this result is purely related to personal benefits that come from the EU (e.g. } \\
\text { Erasmus program). Thus due to this, it is argued that the lack of knowledge about the EU } \\
\text { itself opens the doors for propaganda and false information among young people. } .^{15^{*}}\end{array}$ \\
\hline 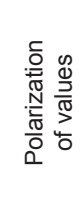 & & $\begin{array}{l}\text { According to Ramonaite, when assessing the West-East values divide in society } \\
\text { the public attitude towards homosexuals can be used as a litmus paper. }{ }^{16^{*}} \text { Fol- } \\
\text { lowing this idea, it can be noted that according to the } 2016 \text { survey only } 12 \% \text { of } \\
\text { young people express the distrust in homosexual people. }{ }^{17^{*}} \text { Consequently, one } \\
\text { could argue that it is unlikely to find a solid basis in the youth group which could } \\
\text { help an attacker to make them feel like a part of the East. }\end{array}$ \\
\hline
\end{tabular}

${ }^{9 *}$ Ilkevičiūtė J. (2017), “Tyrimas patvirtino: atotrūkis nuo Estijos jau nebejuokinga”. Available at: https:// www.delfi.lt/verslas/verslas/tyrimas-patvirtino-atotrukis-nuo-estijos-jau-nebejuokingas.d?id=76423457, (Accessed: 26 November 2018).

${ }^{10^{*}}$ Pukenė R. (2017), "Daugiau nei 90 proc. Lietuvos jaunimo emigruotų, jei gautų darbą pagal specialybę Vakaruose". Available at: https://www.delfi.lt/projektai/archive/daugiau-nei-90-proc-lietuvos-jaunimoemigruotu-jei-gautu-darba-pagal-specialybe-vakaruose.d?id=74535342, (Accessed: 26 November 2018). ${ }^{11^{*}}$ Pukenė R. (2017), “Uždara apklausa apie emigraciją: skaičiai gąsdinantys”. Available at: https://www.delfi.lt/news/daily/education/uzdara-apklausa-apie-emigracija-skaiciaigasdinantys.d?id=76138815, (Accessed: 26 November 2018).

${ }^{12^{*}}$ Balčiūnaitė S. (2017), “Ketvirtoji emigracijos banga. Kas vis dar verčia bėgti iš Lietuvos?”.Available at: https:/www.lrytas.lt/verslas/izvalgos-ir-nuomones/2017/03/21/news/ketvirtoji-emigracijos-banga-kas-visdar-vercia-begti-is-lietuvos--585803/, (Accessed: 26 November 2018).

${ }^{13 *}$ Petronytė-Urbonavičienė I. (2018), "Ar esame pasiruošę ginti? Visuomenès nusiteikimo priešintis užsienio agresijos atveju apžvalga”, Ramonaitè A. et al. , Kas eitu ginti Lietuvos? Pilietinio pasipriešinimo prielaidos ir galimybès, Vilnius: Aukso žuvys, p. 46.

${ }^{14^{*}}$ Vileikienè E. et al. (2015), Motyvacija tarnauti Lietuvos kariuomeneje, Vilnius: Generolo Jono Žemaičio Lietuvos karo akademija, p. 32.

${ }^{15^{*}}$ Rytų Europos studijų centras (2018), “Kaip jaunimas susipažįsta su Europos Sajunga?”. Available at: https:// www.delfi.lt/news/daily/world/kaip-jaunimas-susipazista-su-europos-sajunga.d?id=76999635, (Accessed: 26 November 2018).

$16^{*}$ Ramonaitè (footnote $1^{*}$ ), p. 145.

${ }^{17^{*}}$ LiJOT (2016), Lietuvos jaunimas ir Europa. Sujungta ir ịtrauki Sajunga. Available at: http://www.lijot. lt/lt/leidiniai/lijot-leidiniai/finish/28-metodiniai-leidiniai/1172-lietuvos-jaunimas-ir-europa-sujungta-iritrauki-sajunga, (Accessed: 27 November 2018), p. 61. 


\begin{tabular}{|c|c|c|}
\hline 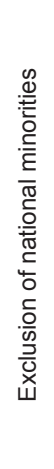 & & $\begin{array}{l}\text { Attitudes towards minorities are notably improving in the country. However, the } \\
\text { situation of the Polish minority in Lithuania remains highly politicized and friction- } \\
\text { al. Not surprisingly due to historical events there is a persistent cliché in the so- } \\
\text { ciety that the Poles would "retake Vilnius" if they would get the chance, while the } \\
\text { minority themselves just feel that their problems are not dealt with effectively. }{ }^{1{ }^{*}} \\
\text { It was observed that after the events in Ukraine the public attitudes towards the } \\
\text { minorities worsened in the country, }{ }^{19^{*}} \text { particularly the idea about questionable loy- } \\
\text { alty to Lithuania played a part in it. Therefore, it can be speculated that there are } \\
\text { latent and negative believes in a society that can be triggered by political unrest. } \\
\text { Thus, if the Polish military forces would ever enter the country to provide the help } \\
\text { in a time of unrest, the escalation of clichés about the Poles and their disloyalty } \\
\text { to Lithuania would be more than likely to rise. } \\
\text { Unfortunately, it is impossible to reasonably evaluate the attitude of the youth } \\
\text { towards the Polish minority; therefore, attitudes will be measured in this analysis. }\end{array}$ \\
\hline
\end{tabular}

\subsection{The Elaboration Likelihood Model, Propaganda's Place in it and Research Hypotheses}

Communication effect analyses are based on the idea that to analyze the effect of a message, it is necessary to understand how people process that message. ${ }^{27}$ A predominant method for analyzing these processes is the Elaboration Likelihood Model. Richard E. Petty and John T. Cacioppo traced a large number of variables affecting the persuasion, but they also observed that there was no consensus on how and when these variables affect the recipients. Eventually, authors concluded that all existing theoretical orientations that sought to understand how communication affects persuasion can be categorized into two different routes of persuasion: the central route (the person carefully and thoughtfully considers the provided information) and the peripheral route (the person follows the cues to evaluate information). ${ }^{28}$

\footnotetext{
18* TV3 (2018), "Lenkų ministras ragina Lietuvą išspręsti didžiausios tautinès mažumos problemas". Available at: https://www.tv3.lt/naujiena/lietuva/974091/lenku-ministras-ragina-lietuva-isspresti-didziausiostautines-mazumos-problemas, (Accessed: 26 November 2018).

${ }^{19 *}$ Jackevičius M. (2015), “Parodè, kaip klydome dèl rusų: tokia padètis nenormali”. Available at: https:/www.delfi.lt/news/daily/lithuania/parode-kaip-klydome-del-rusu-tokia-padetisnenormali.d?id=68209872, (Accessed: 26 November 2018).

${ }^{27}$ Perloff (footnote 9), p. 126.

${ }^{28}$ Petty R. E. and Cacioppo T. J. (1986), “The Elaboration Likelihood Model of Persuasion”, Advances in Experimental Social Psychology (19), p. 125.
} 


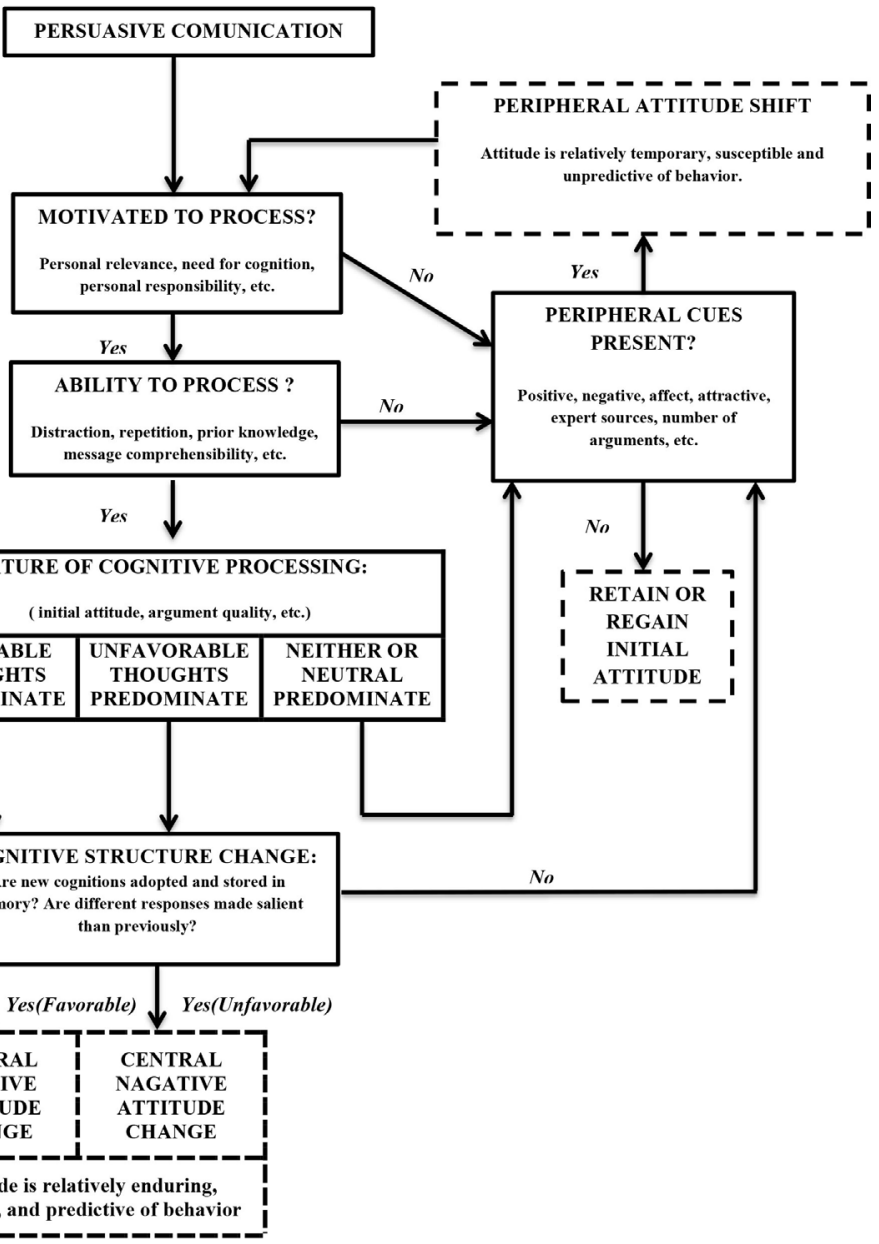

Figure 1. Elaboration Likelihood Model (ELM) ${ }^{29}$

The choice to take one route or another depends on the individual's motivation and ability to elaborate on the presented information. Elaboration is understood as a degree of thinking that a person dedicates to the information provided to them. This is not learning - the difference from learning is the personal contribution to elaboration (e.g. the individual's attitude).$^{30}$ Individuals are neither motivated nor physically able to carefully think through every

\footnotetext{
${ }^{29}$ Ibidem, p. 126.

${ }^{30}$ Petty R. E. and Wegener T. D. (1999), “The Elaboration Likelihood Model: Current Status and Controversies”, Chaiken S. and Trope Y., Dual-Process Theories in Social Psychology, New York: Guilford Press, p. 46
} 
message they receive. ${ }^{31}$ When individuals are motivated or able to elaborate the information presented to them, strong arguments become more persuasive, which means that the person takes the central route, but when individuals are reluctant to elaborate and end up using the cues, it means they are in the peripheral route. ${ }^{32}$ Cues influence persuasion by evoking primitive emotional state associated with the object of the attitude. They can be persuasive even without stimulating the processing of arguments. ${ }^{33}$

It is typical in ELM to use such standard variables as a source, distraction, and repetition. Nevertheless, it can be noted that the list of variables is constantly expanding and already includes such variables as mood, rhetorical questions, etc. ${ }^{34}$ Variables can make an argument more persuasive (they can act as arguments if they are relevant to the topic or help to interpret the argument $)^{35}$ or serve as peripheral cues. ${ }^{36}$ In other words, in the case of high elaboration, they are understood as arguments (e.g. an attractive person speaks about a beauty product and his/her attractiveness is an argument for/supports the effectiveness of the product) or as cues when elaboration is low (e.g. the argument comes from a credible source, so I trust it). ${ }^{37}$

As mentioned in the introduction, it is already possible to identify the youth's bias towards the source; hence the source variable will be explored in this research. It is argued that when information is elaborated through the peripheral route the source factor acts as a simple cue of rejection or acceptance and when it is elaborated in the central route it becomes unimportant and ineffective as a cue. The cue itself is acceptable and effective if it is positive (in this case, the source is credible, expert-approved, socially attractive, etc.), and is less effective in a reverse situation. ${ }^{38}$

To summarize, since propaganda is understood as a phenomenon seeking to manipulate emotions, cues, and symbols, in this study, it is assumed that its dominant route is a peripheral one. Therefore, ELM provides an opportunity to learn whether individuals who are on the peripheral route of information processing are more vulnerable to propaganda stimuli when they are

\footnotetext{
${ }^{31}$ Petty, Cacioppo (footnote 28), p. $128 .$.

${ }^{32}$ Ibidem, p. 152.

${ }^{33}$ Ibidem, p. 134.

${ }^{34}$ Petty, Wegener (footnote 30), p. 55.

${ }^{35}$ Petty R. E. and Cacioppo T. J. (1984), "Source Factors and the Elaboration Likelihood Model of Persuasion”, Advances in Consumer Research (11), http://www.acrwebsite.org/volumes/6328/volumes/v11/NA-11 (Accessed: 26 November 2018).

${ }^{36}$ Petty, Wegener (footnote 30), p. 48.

${ }^{37}$ Ibidem, p. 51.

${ }^{38}$ Petty, Cacioppo (footnote 35 ).
} 
following the source cue. To sum up, the following thematic hypotheses are formed concerning the youth context assessment, i.e., using the topics which according to the contextual analysis could have a fertile ground for propaganda to flourish:

- H1: The attitude towards the country's political institutions will change significantly under the condition of low motivation when the source has a positive characteristic.

- H2: The attitude towards Lithuania's social and economic situation will change significantly under the condition of low motivation when the source has a positive characteristic.

- H3: The attitude towards the European Union's situation will change significantly under the condition of low motivation when the source has a positive characteristic.

- H4: The attitude towards the Polish minority will change significantly under the condition of low motivation when the source has a positive characteristic.

Also, though propaganda is based on manipulation, nevertheless it can seek to produce not just negative, but also a positive change in attitude. In the youth context analysis, there was observed the potential for lowering the attitudes; thus, this study looks into the reaction of propaganda which induces negative attitudinal change and expects attitudes to worsen, which leads to an additional hypothesis (H5): propaganda which stimulates negative attitudinal change will lower attitude.

\section{Methodology}

\subsection{Participants and Design}

A quasi-experiment (i.e., an experiment which takes place in the natural social environment when there is no way to equalize groups) was carried out: 2 (person is motivated/not motivated) $\mathrm{x} 2$ (source is credible/not credible) $\mathrm{x} 4$ (topics: political institutions, socio-economic situation of the country, EU situation, the Polish minority).

Online questionnaires were distributed in which the test, i.e., propaganda in the article or in the snapshot of Facebook post form, was given to participants to read with the questions following in the other pages, i.e., participant was not able to see all questionnaire at once. The questionnaires were distribu- 
ted using Facebook as it is the most popular social network in Lithuania and they were distributed on such Facebook pages like MKIC Group, Apklausos!, Apklausa - pildau, kuriu, dalinuosi!, VGTU, LEU, LSMU, MRU, VMU university student groups and personal profiles. A total of 1,402 persons opened the link and 285 of them (20.3\%) completing the questionnaire fully.

The study selected 18 to 29 -year-old participants $(M=23.21)$. Of 285 filled questionnaires $(n=285) 144$ of them belonged to the experimental group (EG) and 141 belonged to the control group (CG). After selecting the responses made just by ethnic Lithuanians $(n=268$; 95\%), the distribution of participants was as follows: $135(n=135)$ participants in the experimental group and $133(n=133)$ in the control group.

It is important to note that the quasi-experimental study does not fulfill the requirement of internal validity - one cannot claim that there is a definite causal link between $\mathrm{x}$ and $\mathrm{y}$. However, the study does not lose its importance as the ecological validity is fulfilled, i.e., the results of the study are valid in people's daily lives and their natural social environment. Additionally, to my knowledge, in this study, I apply and test a new method to investigate psychological information attacks. The method helps directly i. e. bottom-up, analyze the younger generation of Lithuania, which has not been done before in the context of information warfare.

\subsection{Procedures}

To avoid negative bias towards the word propaganda, the true aim of the study was not revealed to the participants. Instead, it was replaced with a simplified goal - to find out how young people interpret the information provided to them on various topics.

In the first question, the participants had to indicate their attitudes towards the political institutions of Lithuania, the socio-economic situation of the country, the situation of the EU and the Polish minority, which helped to identify pre-attitude before the tests. The questionnaire was further structured into questions and test blocks according to the topic of the hypotheses. At the beginning of each block, questions that help to determine the person's motivation to elaborate were presented. After them, the participants were asked to read the information presented to them and after each reading identifies their attitude towards the political institutions in Lithuania, the socio-economic situation in the country, etc. In all cases, propaganda information that was introduced to the participants promoted a negative attitude towards the object/ topic in question. 
Participants in the experimental group were first provided with credible source stimulus (test categorization: A, C, E, G) followed by unreliable source stimulus (B, D, F, H). The control group was subjected to the same procedures except the sources were unknown/not included in their case. The reliable source stimulus was provided with a passage of the article, increasing the likelihood that participants will complete the questionnaires. The unreliable source stimulus was presented with visual propaganda products with concise text.

\subsection{Stimulus}

The experiment group was presented with one credible source, Delfi, which was used to disguise passages from Sputnik articles. Delfi was chosen because it is the most popular website in Lithuania. Important to note, that participants could pause while answering the questions and, if necessary, checks the validity of the information provided to them, and then go back to completing the questionnaire.

Facebook pages of Lithuanian News (Lietuvos naujienos) and Lithuanian Nationalists 'and Republicans' Union (Lietuviu tautininku ir respublikonu sajun$g a)$ were selected for low credibility source stimuli. The former page acted as a platform to promote messages of the pro-Russian website Bukimevieningi. lt. However, this page places little focus on the problems of the Polish minority and the EU questions. To reflect these topics in the Lithuanian language, content from the Facebook page of Lietuvių tautininkų ir respublikonų sajunga was selected. Both of these pages spread messages that are of a propaganda nature.

\subsection{Operationalization of Variables}

Attitude. It is a socially learnt overall assessment of an object, which can influence thoughts and actions. ${ }^{39}$ The Likert scale (0-10) was used in measuring attitude (0-Dislike a lot, 10-Like a lot).

Motivation to Elaborate. The relevance of the information to the person is the most important aspect accessing the motivation..$^{40}$ Therefore participants' motivation to elaborate the information was calculated individually for each topic. Liker scales (1-4) and several Yes (1) and No (0) type questions

\footnotetext{
${ }^{39}$ Perloff (footnote 9), p. 43.

${ }^{40}$ Petty, Cacioppo (footnote 28), p. 145.
} 
were developed and the motivation index was composed keeping the requirement of a minimum 0.7 of Cronbach's alpha. Participants were divided based on a median (see Annex No. 1.).

Ability. The ability to understand the presented information can be assessed by measuring the intelligence, knowledge level, etc. ${ }^{41}$ However, the participants in the study were presented with ordinary information on the topics that are prevalent in society. Therefore the ability is not an essential variable of this study. Thus, it is used as a control condition and is evaluated accordingly to participants' education. $97 \%$ of the participants had at least a secondary or vocational education, which attests to sufficient cognitive abilities to understand the ordinary and common information in society. While other $3 \%$ of participants did not exhibit significantly different answers compared to the other participants.

Source. The effect of a source as a cue is most acceptable and effective if it is positive; the positive characteristics of a source are beauty, intelligence, comprehensiveness, etc. The positive characteristic used in this analysis is source credibility which was measured by the Likert scale (1-5; 1-Very reliable, 5-Very unreliable).

\section{Results}

\subsection{General analysis-measuring the effect of propaganda information}

During the general analysis of the vulnerability of all participants $(n=268)$ in the study, it was examined whether the negative propaganda has a significant negative effect on participants' attitudes (see Table 3.).

${ }^{41}$ Petty, Wegener (footnote 30), p. 45. 
Table 3. Mean of attitudes and their difference according to the topic - results of repeated measures ANOVA

\begin{tabular}{|c|c|c|c|c|c|c|}
\hline & \\
\hline & $\begin{array}{c}\text { Before } \\
\text { test }\end{array}$ & $\begin{array}{c}\text { After the } \\
\text { test } \\
(C, E, G, A)\end{array}$ & $\begin{array}{l}\text { The differ- } \\
\text { ence after } \\
\text { the first test }\end{array}$ & $\begin{array}{l}\text { After test } \\
(D, F, H, B)\end{array}$ & $\begin{array}{c}\text { The difference } \\
\text { after the } \\
\text { second test }\end{array}$ & $\begin{array}{l}\text { ANOVA } \\
\text { results }\end{array}$ \\
\hline & $\begin{array}{c}M \\
(S D)\end{array}$ & $\begin{array}{c}M \\
(S D)\end{array}$ & $\begin{array}{c}M D \\
{[95 \% \mathrm{Cl}]}\end{array}$ & $\begin{array}{c}M \\
(S D)\end{array}$ & $\begin{array}{c}M D \\
{[95 \% \mathrm{Cl}]}\end{array}$ & $\begin{array}{c}\left.F_{(\mathrm{df} 1,}^{\mathrm{df} 2}\right) \\
\end{array}$ \\
\hline $\begin{array}{l}\text { Attitude towards } \\
\text { the political } \\
\text { institutions of the } \\
\text { country }\end{array}$ & $\begin{array}{c}4.69 \\
(2.06)\end{array}$ & $\begin{array}{l}4.17 \\
(2.16)\end{array}$ & $\begin{array}{c}-0.52^{\star * *} \\
{[-0.77,-0.26]}\end{array}$ & $\begin{array}{l}4.17 \\
(2.15)\end{array}$ & $\begin{array}{c}0.0 \\
{[-0.18,0.18]}\end{array}$ & $\begin{array}{c}18.823^{\star * *} \\
(1.701,454.036)\end{array}$ \\
\hline $\begin{array}{l}\text { Attitude towards } \\
\text { socio-economic } \\
\text { situation of Lithu- } \\
\text { ania }\end{array}$ & $\begin{array}{c}4.60 \\
(2.31)\end{array}$ & $\begin{array}{c}4.69 \\
(2.31)\end{array}$ & $\begin{array}{c}0.09 \\
{[-0.14,0.32]}\end{array}$ & $\begin{array}{c}4.50 \\
(2.49)\end{array}$ & $\begin{array}{l}-0.19^{*} \\
{[-0.38} \\
-0.02]\end{array}$ & $\begin{array}{c}2.192 \\
(1.874,500.372)\end{array}$ \\
\hline $\begin{array}{l}\text { Attitude towards } \\
\text { the European } \\
\text { Union }\end{array}$ & $\begin{array}{l}6.42 \\
(1.9)\end{array}$ & $\begin{array}{l}5.82 \\
(2.05)\end{array}$ & $\begin{array}{c}-0.6^{* * *} \\
{[-0.84,-0.35]}\end{array}$ & $\begin{array}{c}5.60 \\
(2.28)\end{array}$ & $\begin{array}{l}-0.23^{\star *} \\
{[-0.41} \\
-0.05]\end{array}$ & $\begin{array}{c}35.549^{* * *} \\
(1.593,425.206)\end{array}$ \\
\hline $\begin{array}{l}\text { Attitude towards } \\
\text { Polish minority }\end{array}$ & $\begin{array}{l}5.73 \\
(2.4)\end{array}$ & $\begin{array}{l}5.31 \\
(2.3)\end{array}$ & $\begin{array}{c}-0.41^{* *} \\
{[-0.72,-0.11]}\end{array}$ & $\begin{array}{l}5.12 \\
(2.35)\end{array}$ & $\begin{array}{l}-0.19^{\star *} \\
{[-0.34} \\
-0.04]\end{array}$ & $\begin{array}{c}15.451^{* * *} \\
(1.379,368.222)\end{array}$ \\
\hline
\end{tabular}

Note:

$* * *=p<.001 ;$

$* *=p<.01 ;$

$*=p<.05$.

On the topic of increasing the distrust in the political institutions of the country, attitude towards political institutions before the tests was fairly evenly distributed: $37.7 \%$ rated them negatively, $34.8 \%$ expressed a positive attitude and $27.6 \%$ opted for a neutral position.

During the test (Test C) the participants firstly were given a passage of the article by the name "Lithuanian Political Parties Failed. What's Next? “ ("Lietuvos politines partijos sužlugo. Kas toliau?" $)^{42}$ in which it is attempted to picture an apocalyptic situation with the parties in the country. Secondly, the participants were given (Test D) a snapshot of the post from the Figure 2. Attitude change toward political Lithuanian News (Lietuvos nau-institutions (means and confidence intervals)

\footnotetext{
${ }^{42}$ Galvanauskas A. (2018), "Lietuvos politinès partijos sužlugo. Kas toliau?”. Available at: https://sputniknews.lt/columnists/20180506/5909432/lithuania-politines-partijos.html, (Accessed: 10 June 2018).
} 
jienos) page in which it was attempted to create an outrage about the large sums which are being spent by the government on the beetles preservation, but not on preservation of the Lithuanian nation, which author states soon will find itself listed in the Red Book. ${ }^{43}$ In general, attitudes towards the Lithuanian political institutions significantly worsened only after the passage of the article and the second propaganda product did not influence the attitude. It can be argued that the negative propaganda information partially contributed to the statistically significant deterioration in attitude towards the political institutions of the country.

While evaluating the attitude towards the socio-economic situation of Lithuania in the begging it seemed that attitude is leaning toward the negative side ( $46.1 \%)$, nevertheless, $41.4 \%$ of the participants evaluated the country's situation positively and $12.3 \%$ opted for the neutral position.

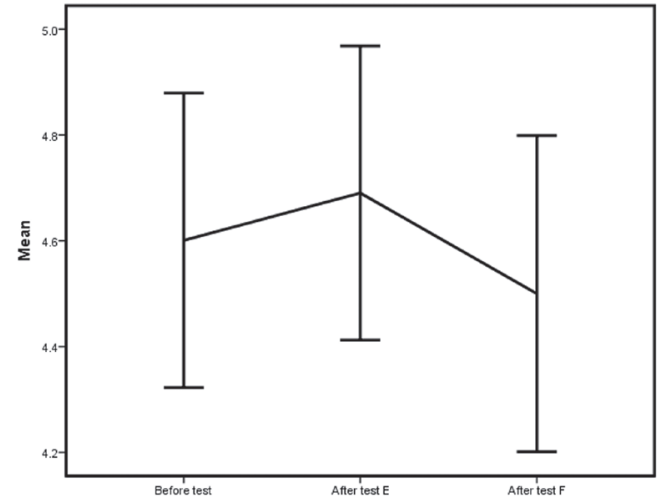

Figure 3. Attitude change towards the socio-economic situation in Lithuania (means and confidence intervals)

During the test (Test E) the participants first had to read a passage from the article by the name "Mother Homeland Callouts: Lithuanians Come Back!" ("Motina Tèvyne šaukia: lietuviai, grižkite!" $\left.{ }^{44}\right)$. In the passage it is laid out that during the independent years of the country the country's population fled it faster than during the Soviet occupation, stating that the situation is so bad that even wars have not yielded results such as existing policies in the country. Secondly (Test F), participants were given a snapshot of a post from the Lithuanian News (Lietuvos naujienos) page in which there were listed and ironically described the achievements of a free and democratic Lithuania, e.g.: "5. Forests are becoming the property of foreign corporations".

It is evident that the negative propaganda information did not significantly affect the participants (see Table 3 .) and their attitude towards the socioeconomic situation in Lithuania remained unchanged.

As it was noted in the context description, Lithuanians evaluate the Eu-

\footnotetext{
${ }^{43}$ The title of the book where endangered species of Lithuania are listed.

${ }^{44}$ Matvejevas V. (2018), “Motina Tèvynė šaukia: lietuviai, grị̌̌kite!”. Available at: https://sputniknews.lt/ columnists/20180111/4829133/motina-tevyne-saukia-lietuviai-grizkite, (Accessed: 10 June 2018).
} 
ropean Union exceptionally positively, therefore this research survey also found a positive perception of the EU (72.8\%) among the participants. Only about $15.7 \%$ of them opted for a neutral position, while $11.5 \%$ expressed a negative view.

In the case of this topic, firstly (test G) participants were given a passage from the article "The Situation with Migrants in Europe Has Worsened - Lithuanians Have Felt It" ("Situacija su migrantais Europoje pablogéjo - tai pajuto ir

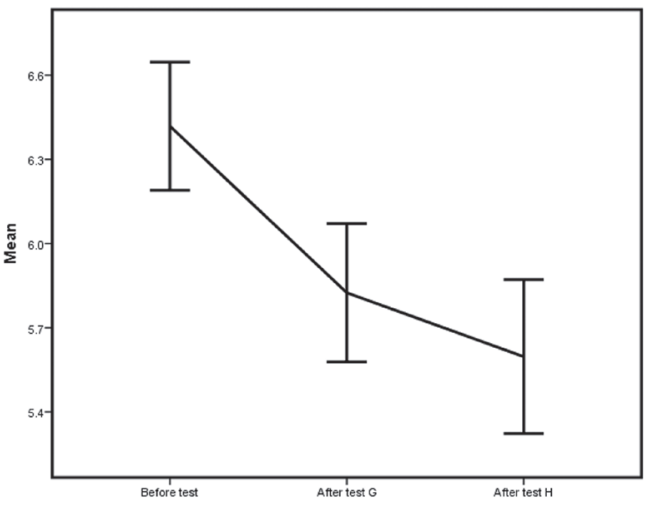

Figure 4. Attitude change towards the European Union (means and confidence intervals) lietuviai"), ${ }^{45}$ which provided statistics demonstrating that EU countries like Italy, Germany, Lithuania, etc. suffer a deterioration of the public opinion regarding the countries' situation after they took in migrants/refugees. Secondly (Test H), participants were given a snapshot of a post from the Lithuanian Nationalists 'and Republicans' Union (Lietuviu tautininku ir respublikonu sajunga) page in which there was a depiction of the hand holding the knife which was complemented with the nationalist's sarcastic comment stating how refugees enriching Europe, with the implication that immigrants in mind are neither refugees, nor are cultured, nor vow to stop the violence. The post provided readers with a hyperlink which lead to a blog where it was stated that the refugees engage in reaping the Germans. ${ }^{46}$

As it can be observed in the figure (see Figure 4.), the article type propaganda product had a greater negative impact on participants than the post snapshot. Notably, according to persuasion communication theory, the first product could be interpreted as a strong propaganda product (i.e., laying out of arguments, etc.) and a snapshot of the post with the short comment and the picture of the hand with the knife could be interpreted as a weak product (i.e., more emotive or symbolic). ${ }^{47}$ Both of them can be influential, only the first one has more power to influence motivated to elaborate the audience, while the second one the unmotivated one. ${ }^{48}$

\footnotetext{
${ }^{45}$ Sputnik (2016), "Situacija su migrantais Europoje pablogèjo — tai pajuto ir lietuviai”. Available at: https://sputniknews.lt/world/20161222/1712235/europieciai-pasymi-padeties-su-migrantais-pablogejima. html, (Accessed: 10 June 2018).

${ }^{46}$ The participants were not able to use the hyperlinks in this study.

${ }^{47}$ Petty, Cacioppo (footnote 28), p.133.

${ }^{48}$ Ibidem, p. 136.
} 
In general, attitude towards the European Union has decreased statistically significantly after both tests; therefore it is evident that negative propaganda information has been very successful in aggravating participants' attitudes towards the EU.

The study found that participants had a relatively positive attitude towards the Polish minority (44\%), with about $35.4 \%$ opting for the neutral position and the remaining $20.6 \%$ identifying a negative attitude towards the minority. While the numbers are promising, the tests have shown a similar attitude susceptibility to propaganda products as with the EU topic.

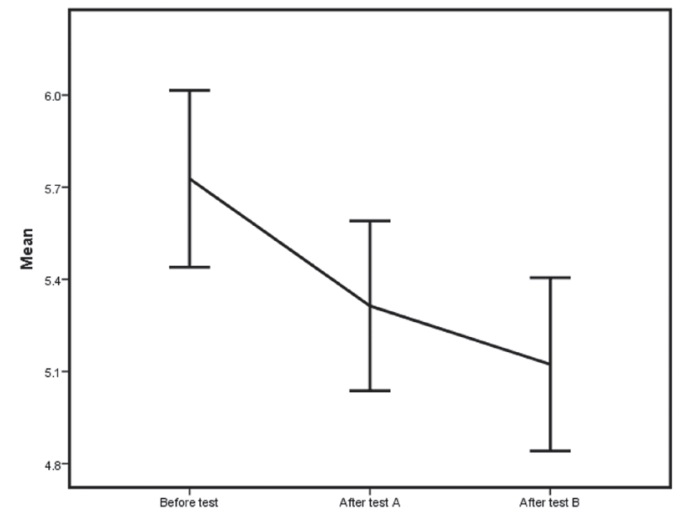

Figure 5. Attitude change towards polish minority (averages and confidence intervals)

Regarding the topic on the possibilities to increase the hostility between Polish minority and ethnic Lithuanians, firstly (Test A) participants were asked to read a passage from the article "Poland and Vilnius Region: Was Yours Will Become Ours?"("Lenkija ir Vilniaus kraštas: buvo tavo - taps müsu?"). ${ }^{49}$ The passage describes an event during the Polish Independence Day where Polish nationalists' campaign, as they claim, routinely attracted thousands of participants. It is alleged that during the event there were posters that had the slogans such as "We remember Lviv and Vilnius" or "Death to the enemies of the homeland" and the author of the article discusses the idea of whether Lithuania should worry about it. The article is unique in that manner that it introduces different stances in the discussion, i.e., why Lithuania should worry and why not. However, one should be cautious in assuming that the propaganda effect disappears if both sides of the question in mind is discussed, on the contrary, some research suggests that presenting the oppositional arguments can increase the persuasion effect. ${ }^{50}$ Secondly (Test B), participants were given a snapshot of a post from the Lithuanian Nationalists 'and Republicans' Union (Lietuviu tautininku ir respublikonu sqjunga) page in which the page authors quoted an article paragraph from the webpage ALKAS. lt where the ideas of the lingering historical hard feelings

\footnotetext{
${ }^{49}$ Petrinis A. (2017), "Lenkija ir Vilniaus kraštas: buvo tavo - taps mūsų?”. Available at: https://sputniknews.lt/columnists/20171120/4404495/lenkija-ir-vilniaus-krastas-buvo-tavo-taps-musu.html, (Accessed: 10 June 2018).

${ }^{50}$ Petty, Cacioppo (footnote 28), p. 134.
} 
between Poles and Lithuanians and the anger of Polish minority youth toward Lithuania were expressed to the readers. Same as in the previous topic the participants were more responsive to the strong propaganda product, i.e., passage of the article, than the weak one, i.e., a snapshot of the post (see Figure 5.). Generally, attitudes towards the Polish minority statistically significantly worsened after both tests.

Consequently, the general analysis of participants revealed that negative propaganda information promotes a significant worsening (H5) of attitude towards political institutions of Lithuania, the European Union situation and the Polish minority, but does not significantly influence attitude towards Lithuania's socio-economic situation. The greatest effects after propaganda to all participants' attitudes (see Table 3.) ware observed after products regarding the state of the European Union situation, followed by the Polish minority and thirdly after the political institutions of the country.

\subsection{Evaluation of the Source Impact on Attitudes of Lithuanian Youth}

In this part of the study, it was analyzed does the manipulation of the source, i.e., the source credibility cue, significantly contributed to the attitude worsening of the participants who were unmotivated to elaborate the given propaganda products. For each topic, the participants of the experiments were divided into four groups based on their motivation to elaborate: motivated-experimental group, unmotivated-experimental group, motivated-control group, and unmotivated-control group. Unfortunately, concerning the Polish minority topic, this step was not possible, because the needed level of Cronbach's alpha (see Annex No. 1) was not obtained during the composition of the motivation index.

After assessing the success of the manipulation (see Annex No. 2), i.e., checking whether the participants evaluated the provided sources as intended, it was found that the Lithuanian youth who participated in the study evaluated the provided sources as it was anticipated - Delfi was understood as a more reliable source compared to the Lithuanian News or Lithuanian Nationalists and Republicans.

Trying to answer the central question of the study, i.e., whether the Lithuanian youth can be vulnerable to the information attacks if their presently identified vulnerabilities are exploited, it was a priority to search for a significant difference between attitudes of motivated and unmotivated participants of the experimental group.

After the first tests, due to present source credibility cue, it was expected that the attitude of unmotivated participants in the experimental group would worsen statistically significant to compare with motivated participants of the 
same group, i.e. they would be more inclined to trust the propaganda information which is disguised with credible source sign Delfi than their counterparts. However, during the research, no statistically significant difference was observed between these two groups. In conclusion, during the data analysis (see Table 4.), no evidence was found to support the main assertion of the study that a youth who are non-motivated to elaborate the information provided would be affected by the source credibility.

Table 4. Attitude mean according to the topic or group, and ANOVA analysis results

\begin{tabular}{|c|c|c|c|c|c|}
\hline & & & Before test & $\begin{array}{c}\text { After test } \\
(C, E, G)\end{array}$ & $\begin{array}{c}\text { After test } \\
(D, F, H)\end{array}$ \\
\hline & & $N$ & $\begin{array}{c}M \\
(S D)\end{array}$ & $\begin{array}{c}M \\
(S D)\end{array}$ & $\begin{array}{c}M \\
(S D)\end{array}$ \\
\hline \multirow{4}{*}{ 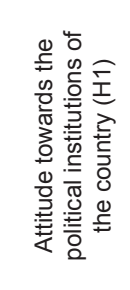 } & Motivated-EG & 46 & $\begin{array}{c}5.24 \\
(1.48)\end{array}$ & $\begin{array}{c}4.54 \\
(1.99)\end{array}$ & $\begin{array}{c}4.61 \\
(1.82)\end{array}$ \\
\hline & Unmotivated-EG & 89 & $\begin{array}{c}4.33 \\
(2.25)\end{array}$ & $\begin{array}{c}3.93 \\
(2.03)\end{array}$ & $\begin{array}{c}4.02 \\
(2.09)\end{array}$ \\
\hline & Motivated-CG & 47 & $\begin{array}{c}4.68 \\
(2.32)\end{array}$ & $\begin{array}{c}4.40 \\
(2.37)\end{array}$ & $\begin{array}{l}4.57 \\
(2.55)\end{array}$ \\
\hline & Unmotivated-CG & 86 & $\begin{array}{c}4.77 \\
(1.94)\end{array}$ & $\begin{array}{c}4.09 \\
(2.24)\end{array}$ & $\begin{array}{c}3.87 \\
(2.11)\end{array}$ \\
\hline $\begin{array}{l}\text { ANOVA } \\
\text { results }\end{array}$ & $\begin{array}{c}F_{(\mathrm{df} 1, \mathrm{df} 2)} \\
\text { (1) }\end{array}$ & - & $\begin{array}{c}2.693^{w^{*}} \\
(3,127.216)\end{array}$ & $\begin{array}{c}1.043 \\
(3,264)\end{array}$ & $\begin{array}{c}1.896 \\
(3,264)\end{array}$ \\
\hline \multirow{4}{*}{ 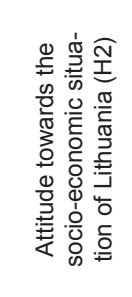 } & Motivated-EG & 44 & $\begin{array}{c}4.52 \\
(1.87)\end{array}$ & $\begin{array}{c}4.39 \\
(1.91)\end{array}$ & $\begin{array}{c}4.66 \\
(1.96)\end{array}$ \\
\hline & Unmotivated -EG & 91 & $\begin{array}{c}4.45 \\
(2.36)\end{array}$ & $\begin{array}{c}4.57 \\
(2.25)\end{array}$ & $\begin{array}{l}4.45 \\
(2.4)\end{array}$ \\
\hline & Motivated-CG & 37 & $\begin{array}{c}5.24 \\
(2.39)\end{array}$ & $\begin{array}{c}5.43 \\
(2.42)\end{array}$ & $\begin{array}{c}5.22 \\
(2.52)\end{array}$ \\
\hline & Unmotivated -CG & 96 & $\begin{array}{c}4.53 \\
(2.42)\end{array}$ & $\begin{array}{c}4.66 \\
(2.47)\end{array}$ & $\begin{array}{c}4.20 \\
(2.73)\end{array}$ \\
\hline $\begin{array}{l}\text { ANOVA } \\
\text { results }\end{array}$ & $\begin{array}{c}F_{(\mathrm{df} 1, \mathrm{df} 2)}\end{array}$ & - & $\begin{array}{c}1.125 \\
(3,264)\end{array}$ & $\begin{array}{c}1.623 \\
(3,264)\end{array}$ & $\begin{array}{c}1.580 \\
(3,264)\end{array}$ \\
\hline \multirow{4}{*}{ 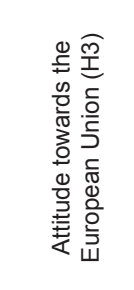 } & Motivated-EG & 66 & $\begin{array}{c}6.39 \\
(1.97) \\
\end{array}$ & $\begin{array}{c}6.05 \\
(1.88)\end{array}$ & $\begin{array}{c}5.95 \\
(2.14)\end{array}$ \\
\hline & Unmotivated -EG & 69 & $\begin{array}{c}6.09 \\
(1.79)\end{array}$ & $\begin{array}{c}5.54 \\
(2.02)\end{array}$ & $\begin{array}{c}5.39 \\
(2.13)\end{array}$ \\
\hline & Motivated-CG & 54 & $\begin{array}{c}7.00 \\
(1.82)\end{array}$ & $\begin{array}{c}6.50 \\
(1.92)\end{array}$ & $\begin{array}{l}6.30 \\
(2.11)\end{array}$ \\
\hline & Unmotivated -CG & 79 & $\begin{array}{c}6.33 \\
(1.92)\end{array}$ & $\begin{array}{l}5.43 \\
(2.19)\end{array}$ & $\begin{array}{l}5.00 \\
(2.48)\end{array}$ \\
\hline $\begin{array}{l}\text { ANOVA } \\
\text { results }\end{array}$ & $\underset{(\mathrm{df1}, \mathrm{df} 2)}{F}$ & - & $\begin{array}{c}2.496 \\
(3,264)\end{array}$ & $\begin{array}{c}3.755^{*} \\
(3,264)\end{array}$ & $\begin{array}{l}4.393^{* *} \\
(3,264)\end{array}$ \\
\hline \multicolumn{6}{|c|}{$\begin{array}{l}{ }^{* *}=\mathrm{p}<.001 ;{ }^{* *}=\mathrm{p}<.01 ; \\
{ }^{*}=\mathrm{p}<.05 .\end{array}$} \\
\hline
\end{tabular}


Therefore, there is no apparent reason to believe that the vulnerability of the youth that is passive regarding the information they encounter, essentially increases if it originates from credibly looking source.

\section{Conclusions}

The results of the data analysis revealed that Lithuanian youth who participated in the research, even if they were not motivated to elaborate propaganda information provided, were resistant to the source credibility cue. Propaganda was not more effective just because it was provided from an allegedly reliable source. It has to be noted, that this conclusion does not apply to attitude towards the Polish minority due to the issue which arose while constructing the motivation index.

Nevertheless, we cannot interpret this youth resistance as unequivocal. Regarding the general analysis, the attitudes of all participants got lower concerning the situation of the European Union, political institutions of the country and the Polish minority, but did not change concerning the socioeconomic situation of Lithuania. This indicates that other variables that were not analyzed in this study were operational during the quasi-experiment. This may be viewed from two perspectives: from the perspective of participants or the perspective of propaganda products.

As for the first perspective, for example regarding the topics of interest, it would be primarily beneficial to grasp/gather the predominant beliefs of the youth audience and analyze to what extent they are outspread in the audience. Beliefs are one of the main components of attitude, so collection of predominant ones would provide a frame for grouping experiment participants accordingly to their predominant beliefs and thus looking for differences in propaganda effectiveness (e.g. those who share the belief that there is no one they can vote for in elections will tend to agree more strongly to negative propaganda products and their negative attitude towards the political institutions will become stronger (i.e., motivated reasoning). However, such type of research may only be useful for exploring prevailing believes in the society or if a need to develop strategies to fight them arises. It is unlikely that it would be useful in the events if temporary movement or momentary dissatisfaction arises in society because this kind of research might take a long time to carry out and founded beliefs might not always be long-term or immutable.

As for the second perspective, it was observed that in the case of the European Union and the Polish minority topics, participants' attitudes altered 
more after articles' passages than after snapshots. In the frame of the Elaboration Likelihood Model, the passage of the article could be interpreted as a strong propaganda product (i.e., laying out of arguments, etc.) and snapshot as a weak one (i.e., more emotive or symbolistic). At the beginning of this study, when considering the relationship between the Elaboration Likelihood Model and propaganda, it was assumed that, due to the reason that propaganda heavily relies on manipulation of the cues (i.e., emotions, etc.), it most likely operates just through the peripheral path of Elaboration Likelihood Model. Therefore, it was assumed that the propaganda effect would be most successful on individuals who are non-motivated (i.e., those who go through the peripheral route) to elaborate the provided information. Nevertheless, the observed susceptibility to the propaganda of experiment participants in general analysis and the different effects according to propaganda products lead to the assumption that the whole model, i.e., both the central and peripheral paths of the Elaboration Likelihood Model, may be applied in research on the effects of propaganda.

To conclude, it can be assumed that there is a substantial basis for further exploration of Lithuanian youth attitude vulnerability to propaganda regarding the EU situation, political institutions of the country and Polish minority topics.

March 2019 


\section{Annex No. 1. Motivation to Elaborate Scales According to the Topics}

\begin{tabular}{|c|c|}
\hline Topic & Composition of the index and its testing \\
\hline 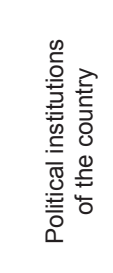 & $\begin{array}{l}\text { The motivation was measured by asking participants to answer the questions about voting } \\
\text { in the } 2016 \text { Parliamentary elections }(1-Y e s ; 0-N o) \text { and about participant's membership in a } \\
\text { political party or civic organization }(1-I \text { am a member or was a member earlier; } 0-\text { I have never } \\
\text { been a member). To generate a general motivation index, these questions were combined } \\
\text { with additional Likert ( } 1-4) \text { scale questions regarding the interest in political news, frequency of } \\
\text { commenting/sharing such type news on social media and other political self-expression within } \\
6 \text { months }(4-\text {-Always; } 3-\text { Often; } 2-\text { Sometimes; } 1 \text {-Never). Combining all the questions was reach } \\
\text { Cronbach's } \alpha(\alpha=0.64) \text { which was too low to design the index. Sufficient } \alpha \text { was obtained with } \\
\text { Likert }(1-4) \text { type questions }(\alpha=0.7, M d=6) \text {. }\end{array}$ \\
\hline 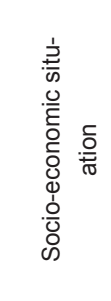 & 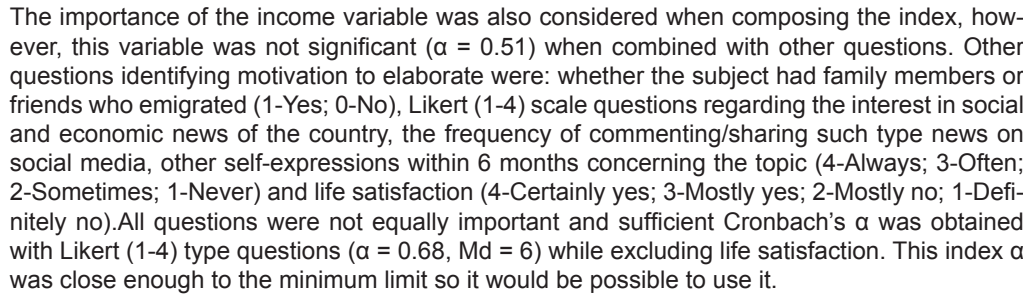 \\
\hline 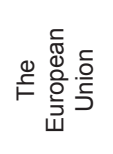 & $\begin{array}{l}\text { The motivation was measured by asking participants to answer the questions about voting in } \\
\text { the } 2014 \text { European Parliament elections (1-Yes; 0-No) and Likert (1-4) type questions regarding } \\
\text { the interest in EU news, the frequency of commenting/sharing such type news on social media } \\
\text { and the participation in EU projects and events within } 6 \text { months (4-Always; 3-Often; 2-Some- } \\
\text { times; } 1 \text {-Never). All variables composed the index }(\alpha=0.76, M d=6) \text {. }\end{array}$ \\
\hline 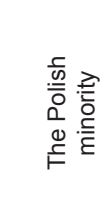 & $\begin{array}{l}\text { The motivation was determined by asking participants to indicate do they have family members } \\
\text { or friends ( } 1 \text {-Yes; } 0-\mathrm{No} \text { ) who is polish. In order to generate a general motivation index, these } \\
\text { questions were combined with additional Likert (1-4) scale questions regarding the interest in } \\
\text { polish minority news, frequency of commenting/sharing such type news on social media within } \\
6 \text { months as well as the question of how often people encounter this minority in their daily lives } \\
\text { (4-Always; } 3-\text { Often; } 2 \text {-Sometimes; } 1 \text {-Never). In the case of this topic, the variables did not ex- } \\
\text { plain data dispersion }(\alpha=0.44) \text {, so no index was created. }\end{array}$ \\
\hline
\end{tabular}

Annex No. 2. Manipulation Control, Sign test results and stimulus comparison

\begin{tabular}{llcc}
\multicolumn{1}{c}{ Sources } & DELFI & $\begin{array}{c}\text { Lithuanian } \\
\text { News } \\
\text { (Lietuvos } \\
\text { naujienos) }\end{array}$ & $\begin{array}{c}\text { Union of Lithuanian } \\
\text { Nationalists and Repub- } \\
\text { licans } \\
\text { (Lietuvos tautininku ir } \\
\text { respublikonu sajunga) }\end{array}$ \\
\hline DELFI & $-2.516^{*}$ & $-2.516^{*}$ & $-2.279^{*}$ \\
\hline Lithuanian News & & & -1.678 \\
\hline $\begin{array}{l}\text { Union of Lithuanian } \\
\text { Nationalists and } \\
\text { Republicans }\end{array}$ & $-2.279^{*}$ & -1.678 & \\
\hline
\end{tabular}

Sign test results (z)

Note:

$* * *=p<.001 ;$

$* *=p<.01$

$*=p<.05$. 